\title{
Aftermath of Gorkha-Nepal Earthquake 2015: Lessons Learnt
}

\author{
Meen B Poudyal Chhetri* \\ Queensland University of Technology (QUT), Australia
}

Submission: January 02, 2018; Published: August 07, 2018

Corresponding author: Meen B Poudyal Chhetri, PhD, Post Doc, Adjunct Professor, Queensland University of Technology (QUT), Brisbane, Australia, Email: meen.chhetri@yahoo.com

\begin{abstract}
Nepal is prone to various types of natural as well as human induced disasters such as: earthquakes, floods, landslides, fires, epidemics, avalanches, windstorms, hailstorms, lightning, glacier lake outburst floods, droughts and extreme weather events. Among all these disasters earthquake is the most scary and damaging. The effects of a disaster, whether natural or human induced, are often far reaching. In addition to the natural factors, the losses from disasters are increasing due to the human activities and absence of proactive legislations. Fundamentally, the weak structures have been found as the major cause of infrastructure collapse in earthquakes. This emphasizes the need for strict compliance of town planning bye-laws and earthquake resistant building codes. Thus, proactive disaster management legislation focusing on disaster preparedness is necessary. This paper analyses the critical gaps responsible for emphasizing the seismic risk and of factors that would contribute towards seismic risk reduction to enable various stakeholders to address the critical areas for improving seismic safety in Nepal and other earthquake prone countries. Additionally, this paper aims to pinpoint the deficiencies in disaster management system in Nepal with reference to the devastating earthquake of 25 April 2015 and suggest appropriate policy and advanced technical measures.
\end{abstract}

Keywords: Earthquake; Proactive; Impact; Legislation; Measures

\section{Introduction}

An earthquake disaster is the most terrifying disaster in Nepal, but Nepal is no limited to just earthquakes; there are also disasters such as floods, landslides, fires, avalanches, windstorms, hailstorms, lightning, glacier lake outburst floods, epidemics, droughts and so on. There have been many occurrences of earthquake disasters in Nepal that have caused heavy casualty losses and physical property damages, adversely affecting the overall development of the country. Nepal's proximity to earthquake hazards is mainly due to her young and fragile geology. Haphazard and unplanned settlements and poor construction practice are the other reasons that have made her highly vulnerable to earthquake impacts. Nepal may have encountered many earthquakes throughout history; it has the record for the greatest loss of life dating back to the 12th century. Since then Nepal has encountered 16 major earthquakes, including the devastating Gorkha-Nepal earthquake of 25 April 2015 (Figure 1).

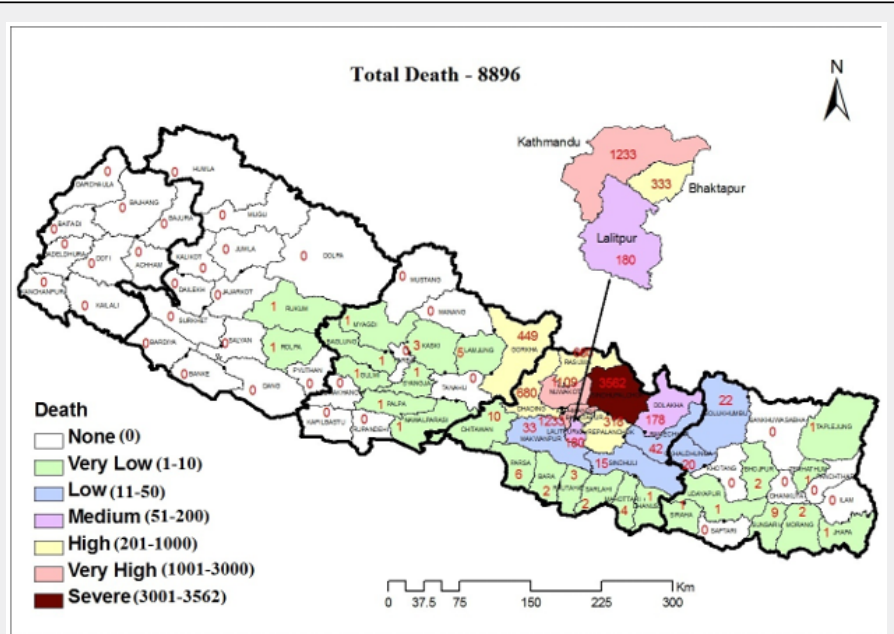

Figure 1: Human Deaths byGorkha-Nepal Earthquake.

Source: Ministry of Home Affairs, the Government of Nepal. 
The Gorkha-Nepal earthquake left a trail of miseries that the affected people will continue to combat for years. This is, in fact, a wakeup calls for policy-makers, development experts, civil society and the general public that had not considered unplanned development and haphazard construction as the major causes of loss and damage due to this earthquake. The disaster vulnerability of the country is so serious that Kathmandu, the capital city of Nepal, is number one among the 21 mega cities in the world from the point of view of earthquake risk. (Source: Upreti 2009) [1-5].

\section{Gorkha-Nepal Earthquake of 25 April 2016}

A 7.6ml earthquake struck Nepal on 25 April 2015 (11:56am local time). The epicenter was near the Barpak Village of Gorkha district which is $81 \mathrm{~km}$ northwest from Kathmandu.
The devastating earthquake killed 8,896, with missing 198 and seriously injured 22,302 people and rendered millions homeless. More than six hundred thousand households were fully damaged leaving around three hundred thousand partially damaged. Mostly, old, non-engineered, adobe and masonry buildings collapsed and/or were severely damaged by the earthquake. In addition, some engineered buildings also damaged or collapsed due to poor workmanship and quality of construction materials. The earthquake severely affected 14 districts (Gorkha, Dhading, Rasuwa, Nuwakot, Kathmandu, Lalitpur, Bhaktapur, Kavrepalanchowk, Sindhupalchowk, Dolakha, Sindhuli, Makawanpur, Ramechhap and Okhaldhunga) and another 31 districts affected to varying extents. (NDR 2015). Please see Map 1 below for the number of people died in different districts of Nepal (Figure 2).

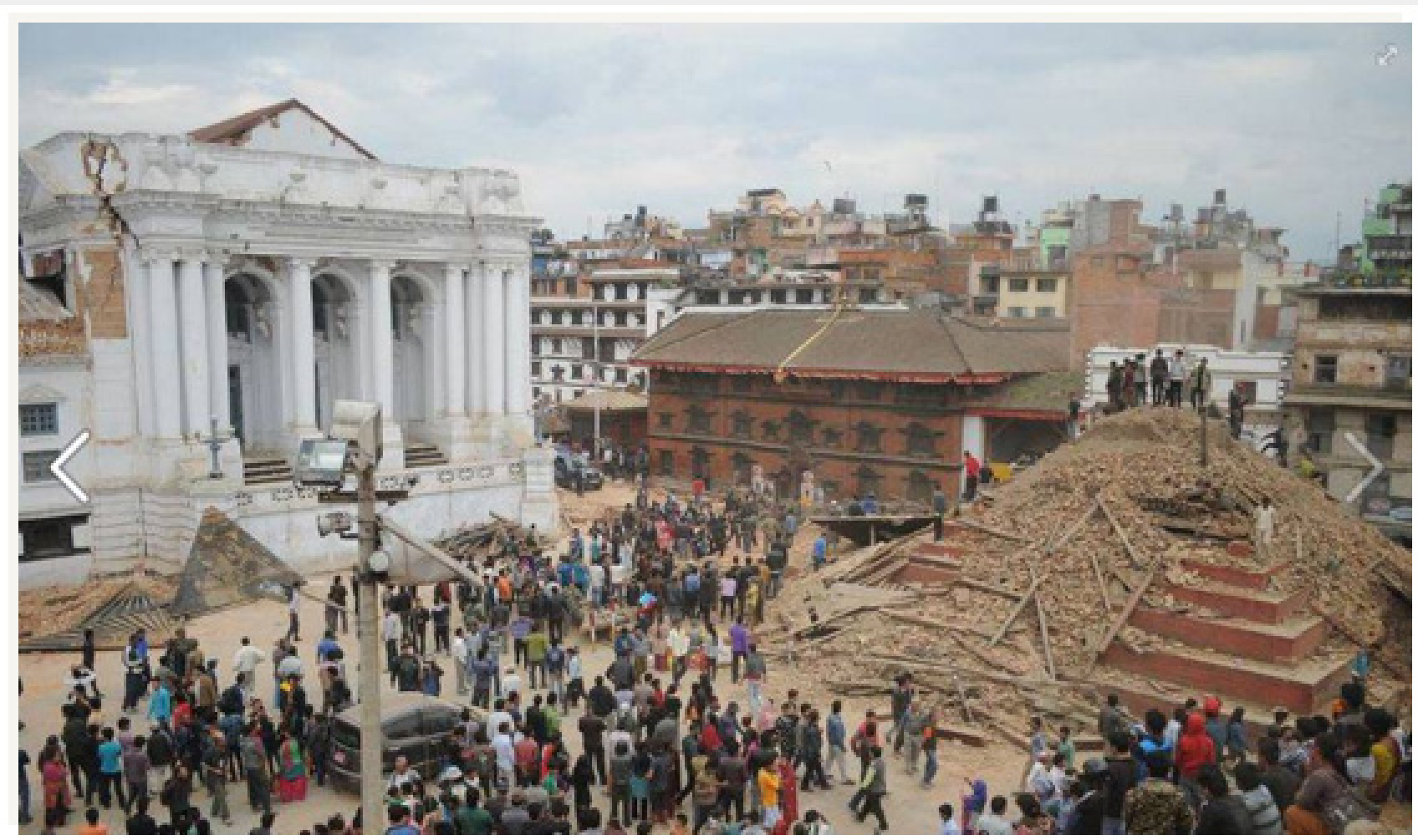

Figure 2: Damaged Kathmandu Durbar Square which is a Cultural Heritage.

The 25 April earthquake was followed by a number of aftershocks throughout Nepal, with one shock reaching a magnitude of 6.7 on 26 April at 12:54am local time. The 25 April earthquake affected the entire Nepal and also affected some parts of India, Bangladesh and the Tibet Autonomous Region of China. Tremors were also felt in Bhutan and Pakistan. This earthquake was the largest to hit Nepal after the Nepal-Bihar earthquake of 1934. All these major earthquakes established that the casualties were caused mainly due to the collapse of infrastructures [6-10].
On 26 April 2015, the Government of Nepal declared the 14 districts as catastrophic area and appealed for international humanitarian assistance including search and rescue. On 12 May 2015 at 12:50 local time another strong aftershock measuring 6.8 magnitudes struck with the epicentre in Sunkhani of Dolkha district. The epicentre was $76 \mathrm{~km}$ northeast of Kathmandu. This area was already affected by the 25 April quake. The initial quake was followed by several aftershocks including a 5.6 magnitude. This quake toppled already weakened buildings, triggered a series of landslides, which further hampered relief efforts. This quake alone killed more than 100 people (Figure 3). 


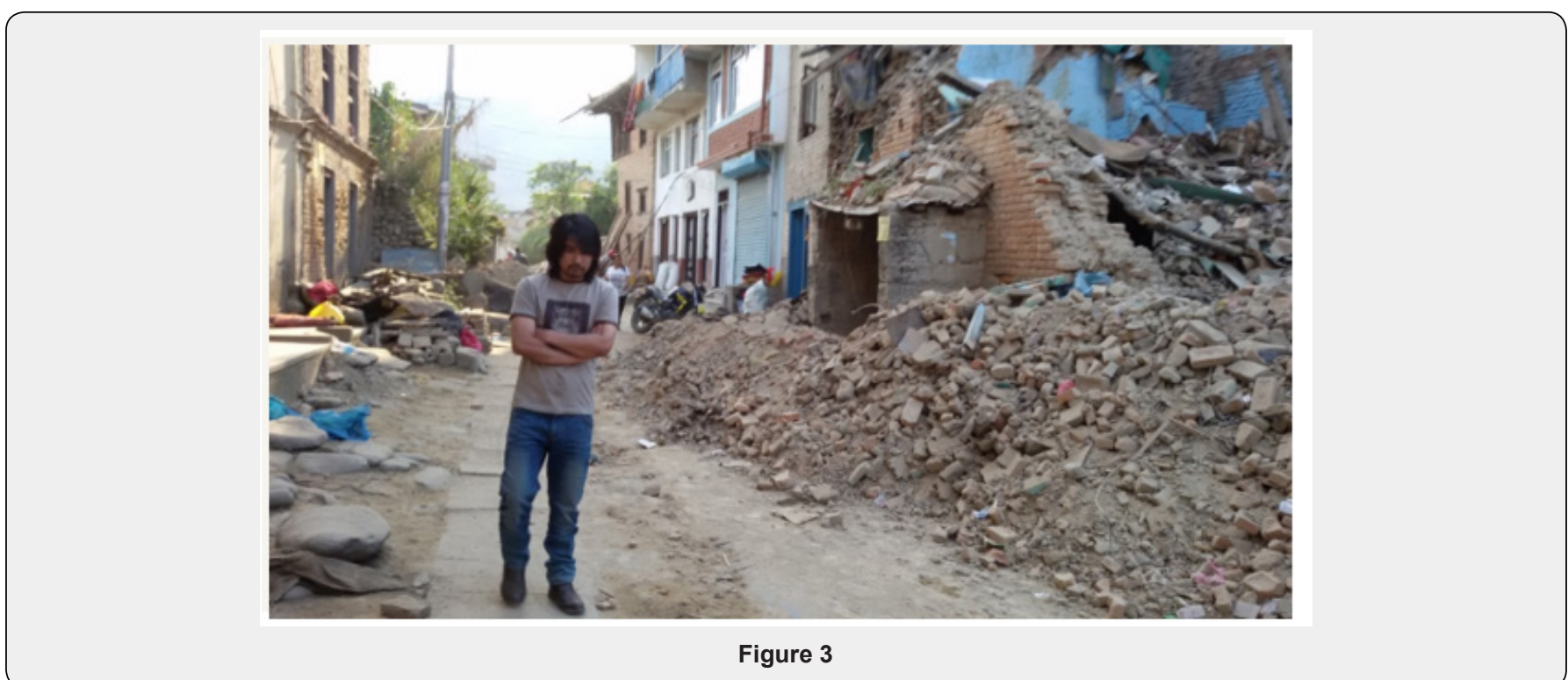

According to the Department of Survey of the Government of Nepal, the movement of tectonic plates that triggered massive earthquake in the country on 25 April caused the altitude of Table 1: Losses Due to the Gorkha-Nepal Earthquake.

\begin{tabular}{|c|c|}
\hline Nos./Amount & Particulars \\
\hline 8,896 & Persons dead \\
\hline 198 & Missing \\
\hline 22,302 & Injured \\
\hline $8,86,456$ & Affected Families \\
\hline $6,49,815^{*}$ & Displaced Families \\
\hline $6,04,930$ & Houses Damaged (Fully) \\
\hline $2,88,856$ & Houses Damaged (Partially) \\
\hline NPRs. 706 billion US\$ 7 billion\# & Total Material Loss \\
\hline
\end{tabular}

Source: Ministry of Home Affairs; Situation Report* of NRCS \& PNDA\# Report, NPC, the Government of Nepal.

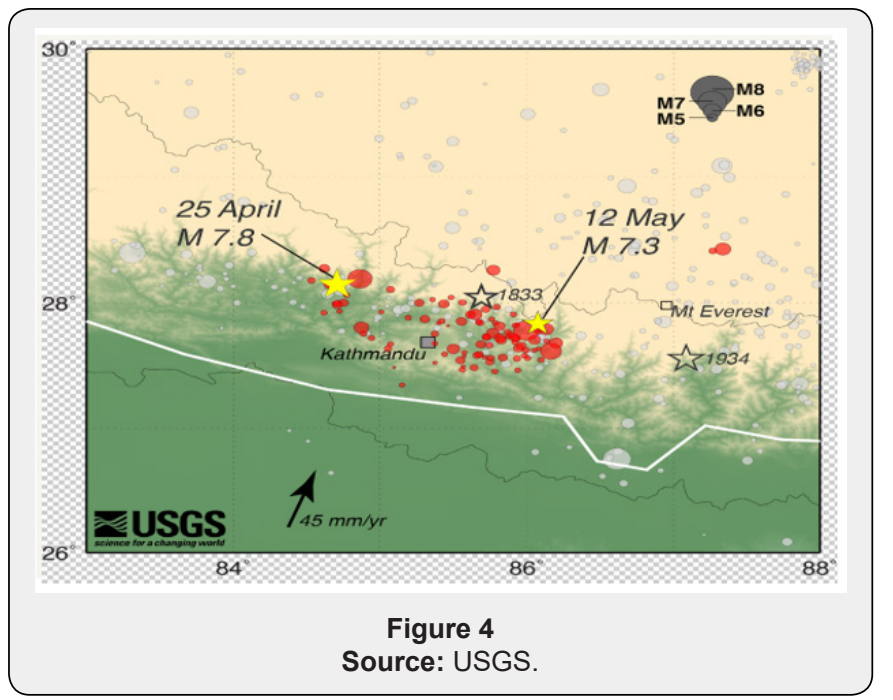

As shown in Table 1 above, it is estimated that the total value of disaster effects (damages and losses) caused by the earthquakes is NPR 706 billion or its equivalent of US\$ 7 billion. Of that amount, NPR 517 billion (or 76 percent of the
Kathmandu Valley to increase by 80 centimeters. In total 438 numbers of aftershocks with Local magnitude $>=4$ have been recorded till 6 March 2016 [11-15]. total effects) represents the value of destroyed physical assets, and NPR 189 billion (24 percent of the total effects) reflects the losses and higher costs of production of goods and services arising from the disaster. These estimates are based on the aggregation of information and data collected across sectors of social and economic activity and checked to avoid duplication of numbers. (Source: PDNA Report 2015, NPC) (Figure 4).

\section{Causes, Consequences and Scale of the Earthquake}

This earthquake occurred in a geological collision zone, where the Indian tectonic plate pushes north into the Eurasian plate, moving the ground an average of $2 \mathrm{~cm}$ a year. Over decades, stress built up along a stretch of the fault line, which is called the Main Himalayan Thrust (MHT) fault, close to Nepal's capital Kathmandu. In this area, the boundary between the two plates had become locked - stuck together by friction and so immobile - building up energy that only a major earthquake could release.

Prof Jean-Philippe Avouac of University of Cambridge believes that the quake on 25 April only released part of this pent-up pressure. "If the earthquake had ruptured all the locked 
zone all the way to the front of the Himalayas, it would have been a much larger earthquake. This is a place that needs attention, and if we had an earthquake today, it would be a disaster because of the density of population not just in western Nepal but also in northern India, in the Gangetic plain. We don't want to scare people, but it is important they are aware that they are living in a place where there is a lot of energy available," says Prof Avouac.

Some other new data also revealed that the devastating quake that hit Nepal in 25 April did not release all of the stress that had built up underground and some of this stress has shifted west to an area stretching from the west of Pokhara in Nepal to the north of Delhi in India. The research is published in the journals Nature Geoscience and Science. Its authors say more monitoring is now needed in this area. Therefore, a major earthquake there is already long overdue: the last happened in 1505 and is estimated to have exceeded M8.5. The researchers say the new stress that has moved there could already be adding to the tension that has been building up over five centuries.

Please see Map 2 below for the scale of the 25 April 2016 Gorkha-Nepal Earthquake and the major aftershock of 12 May 2016.

Agony — Let's hope it will not happen again

Commenting on the research, Prof David Rothery from Open University said: "Monitoring techniques have now advanced to the stage where we can work out how a previously 'locked' fault has 'unzipped' during the couple of minutes that it takes a major earthquake to happen."Lives would be saved by drilling school children in western Nepal and the nearby plains of northern India in how to react in the event of an earthquake and in ensuring that at least school buildings are adequately constructed to survive seismic shaking."

\section{Response}

Immediately after the earthquake, although there was chaos, confusion and distress -- National Emergency Operation Centre (NEOC) at the Ministry of Home Affairs was activated at levelIV by following the National Disaster Response Framework, 2014 and Standard Operating Procedure (SoP). Soon after the quake the Prime Minster, Home Minister, other Ministers, Chief Secretary, Secretaries, high level officials and the chief of security forces were present at the NEOC. Within two hours, the Central Natural Disaster Relief Committee (CNDRC) meeting was held and made necessary decisions for immediate relief and response. Soon after, the cabinet meeting endorsed the decisions of CNDRC including declaration of catastrophic area and appealed for international assistance. Central Command Post was established under the leadership of Home Secretary. Security forces were mobilized immediately for Search and Rescue (SAR) operation with heavy equipment and helicopters. Helicopters were used in remote areas for SAR operation from Nepal Army, India, China, U.S.A. and private sector. Altogether 66,069 Nepal Army personnel, 41,776 Nepal Police, 24,775 Armed Police Force and 22,500 Civil Servants were mobilized for response. In total 7,606 people were rescued by 4,299 flights of Nepal Army, foreign and private sector helicopters. A total of 12,295 people were rescued by air lift and land routes. (Source: 1 month report of MoHA on 26 May 2015).

A number of volunteer groups, local people, youths, civil societies, media and political parties provided significant assistance to the affected people during the response. Several International and local NGOs, Red Cross and Red Crescent Societies and United Nations Organizations supported from the beginning of the response. There has also been a considerable amount of aid distributed by various social organizations, private and corporates. This includes skilled technical personnel such as doctors, nurses, engineers as well as unskilled personnel and in-kind contributions. Despite the lack of sufficient search and rescue equipment and resources, security forces played a significant role in search and rescue and relief works.

\section{Problems Associated with the Gorkha-Nepal Earthquake}

The response work was highly criticized as it was not prompt and well organized. A key complaint was of a slow and inadequate relief effort, which failed to reach in due time to many of the affected people of remote, rural and hilly areas. It was mainly due to the lack of a strong road network and transport resources, especially helicopters, and a serious bottleneck at the airport. Major delays were also caused by bureaucratic procedures and even bitter mutual accusations - both in public and private-over who was to blame and who should be in control of resources. Thousands of people in the affected districts still lack even the most rudimentary shelters. Past monsoon and chilling winter exposed many temporary households to extreme weather, cold and increased diseases, but also to further collapses of houses damaged during the earthquake. As a result hundreds of people died during the severe winter. Earthquake victims have repeatedly complained that the rice distributed in various districts by the World Food Program (WFP) through Nepal Red Cross Society (NRCS was "substandard and inedible".

This mega disaster will have a long-term effect on Nepal's economy and development efforts for several years. The agriculture, industry, tourism and service sectors have been badly affected. Agitation in Tarai region of Nepal and controlled supply of fuel and other consumable goods by India has further worsened the situation. This is a major set-back indeed. The economic loss by the blockade by India was more than the loss caused by the earthquake. In view of the slow recovery process, it seems that it will take a long time and will pass through the similar situation as Haiti has faced since its own earthquake in 2010. This is high time for Nepal to learn a lesson from Haiti while Nepal must not repeat the mistakes done by the Haitian government after the 10 January 2010 earthquake.

\section{International Cooperation and Disputes}

For any government, it would be difficult to cope alone with such a huge disaster. In such a situation, international assistance 
is pertinent for response and rehabilitation works. Therefore, on 26 April 2015, the Government of Nepal declared an emergency in the worst affected districts and made a request for international humanitarian support. However, it is more difficult in Nepal due to some of its inaccessible landscape and difficult terrain. Unfortunately, it risks adding a man-made calamity to a devastating natural disaster. During the course of search and rescue efforts, an American helicopter crashed near the NepalChina border resulting in the sad demise of five American soldiers, two Nepali soldiers and five disaster victims.

Actually, relations between the Nepal government and the international community were not conducive for some time right after the earthquake. There was the problem of mutual trust. The donor communities didn't fully trust the government; questioning its ability to deliver services while the government wasn't happy because the donor communities wanted to spend the assistance money through their agents. On the other hand the Nepalese government wanted any assistance to be collected into the Prime Minister Relief Aid Fund and then channel to the affected areas. In other words, the government wants to adopt one door policy. However, the relationship between the Nepal Government and International Community did improve as time passed.

\section{Foreign Aid Commitments}

There was a donor community meeting on 25 June 2015 in Kathmandu, Nepal. The highest-profile international donor conference ever held in the country amassed more than 300 delegates from 56 nations, development partners and the donor community. In a major boost to Nepal's reconstruction and recovery efforts, development partners and the donor community have pledged $\$ 4.4$ billion in aid during the International Conference on Nepal's Reconstruction (2015). This has come as a huge relief to the reconstruction and recovery bid and brought cheers to the government.

\section{Formation of Reconstruction Authority}

A high level Reconstruction Authority has been formed under the chairmanship of Prime Minister, including four ministers picked by PM, a chief executive officer, Vice-chairperson of the National Planning Commission, Chief Secretary and three experts having 15 years of experience in related field after completing post-graduate degree in infrastructure engineering, law, economics, management, economic or social development as members. The tenure of the authority will be five years and the government can either extend its term by a year if the tasks of reconstruction remained incomplete or assign any other body for the same. The CEO can recommend chairman to appoint secretary of the authority from among government officers. Laws related to acquiring and registering land, public procurement and Environment Impact Assessment will not be applicable in the quake-hit areas to accomplish the task of reconstruction rapidly.

\section{Reconstruction Authority's Salient Tasks}

I. To determine total loss due to earthquakes

II. To acquire necessary land following legal procedures

III. To order authority concerned to remove physical structures after providing compensation to owners

IV. To coordinate with different bodies for effective implementation of reconstruction work

V. To order owners to remove their damaged structures or to remove them at their cost.

The authority would direct the concerned ministries to accomplish necessary work of reconstruction providing them with necessary budget from a separate fund created for reconstruction work.

\section{Challenges, Gaps and Lessons Learnt}

The total impact of the 2015 Gorkha-Nepal Earthquake is still going on. There were psychosocial consequences of that devastating earthquake disaster. The nightmare and traumatic situation caused by the disasterupon many people particularly among the children and adolescents are still there and may remain for a prolonged time.

The following challenges and gaps were identified after the earthquake:

1. Search and Rescue (SAR) works carried out by the security personnel of Nepal and foreigners was commendable. But it was slow and inadequate while they failed to reach in due time in the remote, rural and hilly areas and it was not well-organized. Of course, sometimes it was compounded by the lack of equipment, road network, transport, and well-trained skilled human resources.

2. Delay and serious lapse in damage and need assessment was felt all the time. There was a gap between the need of the affected people and delivery of services.

3. Open spaces for temporary settlement of the displaced population were lacking.

4. Although there was large number of international SAR team -- they could not contribute considerably as expected. There were 4,521 team members from 34 countries and they were able to save only 16 lives with the help of Nepalese security personnel. The cost incurred for the foreign team was quite huge. So, it can be assessed that the return was quite low in comparison to the investment upon the foreign team.

5. Emergency warehouses, prepositioning of relief materials with proper inventory were also lacking.

6. Debris management was found as one of the big problem basically because of the lack of debris management equipment, tools and techniques. 
7. Accurate and proper communication between District Emergency Center (DEOC) and Central Emergency Operation Centre (EOC) was not effective.

8. A weak database and an absence of modern technology were other bottlenecks for poor response in Nepal.

What are the lessons?

\section{Critical areas of concern of the Nepal earthquake can be summarized as following}

a) Lack of awareness as well as coordination among disaster management stakeholders;

b) Inadequate attention to structural mitigation measures in the engineering education syllabus;

c) Weak law enforcement and monitoring of building codes and town planning;

d) No licensing system for engineers and masons;

e) Absence of earthquake resistant features in nonengineered construction in sub-urban and rural areas;

f) Lack of training for professionals in earthquake resistant construction practices; and

g) Lack of adequate preparedness and response capacity among various stakeholder groups.

The biggest lesson Nepal learnt from this earthquake is that the threat of earthquakes will never end while Nepal is in seismically very active zone. The best way to be safe from earthquake hazards is to build earthquake resistant infrastructures. There should be no COMPROMISE in building earthquake resistant infrastructures. Hence, this is high time to Build Back Better (BBB).

All most all casualties were due to the collapsed infrastructures. Another lesson we learnt is that if similar high intensity earthquake in the U.S.A., Japan or other equally developed nations do not lead to enormous loss and damage to human lives and physical properties as the infrastructures in these countries are earthquake resistant. This emphasizes the need for strict compliance of town planning bye-laws and building codes in Nepal.

It has been realized that in the past the government did not paid due attention to Disaster Risk Reduction (DRR). DRR has not been a priority for the government. The government was found too weak in preparedness at all levels. Inadequate legal instruments and poor implementation of existing legislations have also been identified as a factor for losses and damages. The government was never serious in DRR. Not only the government, butalso the NGO and INGOs were entangled with mounds of paper work (preparation of reports etc.) and discussions (seminars, workshops, interactions, meetings, visits etc.). Overall, less emphasis was given to actual hardware considerations. Resource constraints and managerial weaknesses were and are still there.

\section{Way forward and recommendations}

In view of the major disasters like the devastating earthquake of 25 April 2015, Nepal should adopt long-term and sustainable efforts to mitigate the hazards. Although disaster management and risk reduction may be considered expensive in the light of competing demands for resources in a developing country like Nepal, this is high time for the government to invest on considerable activity and resources into preparing for and responding to familiar and unexpected emergencies and disasters before the human and economic consequences of inaction are extensive, unmanageable and more expensive. This paper suggests some basic principles and guidelines to reduce the impact of the potential future earthquake disaster not only in Nepal but also for other earthquake prone countries as well. Following are the basic and fundamentals for earthquake management in Nepal and beyond:

1.1 Construction of earthquake resistant infrastructures;

1.2 Selective seismic strengthening and retrofitting of existing priority structures and lifeline structures - a priority list for structural safety audit, seismic strengthening and retrofitting is required;

1.3 Effective implementation of Building Code and other legislations;

\subsection{Mass awareness and preparedness;}

1.5 Capacity development through education, training, research \& development (R\&D), documentation and information sharing;

1.6 Effective and efficient response during and after emergency

\subsection{Build Back Better (BBB).}

The above basics are necessary to reduce the impact of earthquakes in the short-term as well as in the medium and long-term. They recognize the enormous challenge in improving seismic safety because of the inadequate numbers of trained and qualified civil engineers, structural engineers, architects and masons proficient in earthquake-resistant design and construction of structures. They also recognize the need for imparting training in earthquake-resistant design and construction to faculty members in professional courses and for creating mass awareness on earthquake and other disaster risk reduction features in non-engineered construction in earthquake prone areas.

\section{Conclusion}

As the impacts will forever affect landscape, people, society, and livelihoods in Nepal - there is no choice but to adapt to disasters. Living not only with earthquakes, but also with many other disasters in daily life is the destiny of Nepalese people. Yet, the Nepalese and their neighbors and friends all over the globe, have to reconcile themselves to the fact that tens of kilometers 
beneath where they live, the Indian and Eurasian plates will continue their tussle again and again. In that journey, they must build on the fundamental strengths they possess-social capital and community resilience. Despite a weak government and postconflict political instability, the presence of community-based institutions at sub-national levels maintain a social cohesion and play a constructive role in managing life lines like: drinking water, electricity, forest, and bridges.To rebuild Nepal, the government should call on experts inside and outside the country to engage in interdisciplinary collaboration. Non-governmental organizations, the private sector, experts, intellectuals and the media can contribute in the rebuilding and disaster-preparation efforts and working collaboratively and effectively.

\section{Biography}

The author, Meen B. Poudyal Chhetri earned his Post Doctorate in Disaster Management Policy from the Queensland University of Technology (QUT), Brisbane, Australia. He also holds Ph. D., Master's and Bachelor's degree in Economics and International Law. Currently, Prof. Chhetri is the President of Nepal Center for Disaster Management (NCDM) and Chairman of The International Emergency Management Society (TIEMS)'s paper Review Committee. He is the Adjunct Professor at the Queensland University of Technology, Brisbane, Australia since 1 March 2009. He served as the Director of the Department of Disaster Management of the Government of Nepal from 2001 to 2003. In 2004 He worked as the Deputy Regional Administrator in Hetauda, Nepal. From 1995 to 1996, he was the Chief District Officer and Chairman of District Disaster Relief Committee in Dhading district of Nepal. Prof. Chhetri also held positions of Under Secretary, Investigation Officer and Special Officer in various government agencies of Nepal including the Commission for the Investigation of Abuse of Authority, Ministry of Home Affairs, Ministry of Finance, Ministry of Agriculture and Ministry of Education. Prof. Chhetri is the author of two books and a number of research articles that are published in national and international journals. Prof. Chhetri awarded with AEI Australia Alumni Excellence Awards 2014 by the Government of Australia on 20 January 2014. On 13 October 2014, he is awarded with "DPNet Award" by the Government of Nepal. He is also decorated with several national medals and awards in recognition to this contribution for the development of the nation.

\section{Acknowledgement}

Kind acknowledgements and sincere thanks to Excellous President Alok Roy and all others involved in the organization of the ICDRR 2016 for their support and friendly invitation to me as the Keynote Speaker at the great event.

\section{References}

1. Bhattarai D, Poudyal Chhetri MB (2001) Mitigation and Management of Floods in Nepal. Ministry of Home Affairs, Government of Nepal.

2. Disaster Management in Nepal - A Profile (1994) Government of Nepal, Ministry of Home Affairs, Kathmandu, Nepal.

3. Draft Disaster Management Act (2007) Nepal Center for Disaster Management, Lalitpur, Nepal.

4. Draft Disaster Management Policy (2007) Nepal Center for Disaster Management, Lalitpur, Nepal.

5. Natural Calamity Relief Act 1982 . The Government of Nepal, Nepal.

6. National Strategy for Disaster Risk Management, 2009. The Government of Nepal, Nepal.

7. Nepal Disaster Report 2015. MoHA, DPNet, Nepal.

8. Post Disaster Needs Assessment Report. National Planning Commission, Government of Nepal.

9. Poudyal Chhetri MB (2001) A Practitioner's View of Disaster Management in Nepal: Organization, System, Problems and Prospects. Risk Management: An International Journal, Published by Perpetuity Press Ltd., Leicester, UK, 3(4): 63-72.

10. Poudyal Chhetri MB (1998) Disaster Management Policies, Problems and Measures: The case of Nepal. A Paper Presented in an International Seminar on Water Induced Disaster held from 4 to 6 November 1998 in Lalitpur, Nepal.

11. Poudyal Chhetri MB (1999) Disaster Management in Nepal: Problems and Solutions. An Article Published in the Book on Natural Disaster Management, Edited by Jon Ingleton, Tudor Rose, Holdings Limited, Leicester, England.

12. Poudyal Chhetri MB (2011) Disaster Risk Reduction: Policy Implications for Nepal, Australia and Beyond. Post Doctorate Dissertation submitted at the Queensland University of Technology (QUT), Brisbane, Australia.

13. Problems of Disaster Management in Nepal and Measures to Solve Them (1998). A Report Prepared by a Task Force, HMG/N, Ministry of Home Affairs, Kathmandu, Nepal.

14. http://www.bbc.com/news/science-environment-33807791

15. Various government websites of Nepal e.g. www.moha.gov.np; www. neoc.gov.np; www.domg.gov.np; drrportal.gov.np. 
(C) (1) This work is licensed under Creative DOI: 10.19080/OFOAJ.2018.08.555735

\section{Your next submission with Juniper Publishers} will reach you the below assets

- Quality Editorial service

- Swift Peer Review

- Reprints availability

- E-prints Service

- Manuscript Podcast for convenient understanding

- Global attainment for your research

- Manuscript accessibility in different formats ( Pdf, E-pub, Full Text, Audio)

- Unceasing customer service

Track the below URL for one-step submission https://juniperpublishers.com/online-submission.php 